\title{
Decarbonizing Energy in Bali With Solar Photovoltaic: GIS-Based Evaluation on Grid-Connected System
}

\author{
Ami Syanalia ${ }^{1}$, Fikriyah Winata $^{2}$ \\ ${ }^{1}$ University College London, London, United Kingdom \\ ${ }^{2}$ Department of Geography and Geography Information Science, University of Illinois
}

Received October, 25 2017; Accepted July, 232018

Available online 31 August 2018

\begin{abstract}
In the past century, fossil fuels have dominated energy supply in Indonesia. However, concerns over emissions are likely to change the future energy supply. As people become more conscious of environmental issues, alternatives for energy are sought to reduce the environmental impacts. These include renewable energy (RE) sources such as solar photovoltaic (PV) systems. However, most RE sources like solar PV are not available continuously since they depend on weather conditions, in addition to geographical location. Bali has a stable and long sunny day with 12 hours of daylight throughout the year and an average insolation of $5.3 \mathrm{kWh} / \mathrm{m} 2$ per day. This study looks at the potential for on-grid solar PV to decarbonize energy in Bali. A site selection methodology using GIS is applied to measure solar PV potential. Firstly, the study investigates the boundaries related to environmental acceptability and economic objectives for land use in Bali. Secondly, the potential of solar energy is estimated by defining the suitable areas, given the technical assumptions of solar PV. Finally, the study extends the analysis to calculate the reduction in emissions when the calculated potential is installed. Some technical factors, such as tilting solar, and intermittency throughout the day, are outside the scope of this study. Based on this model, Bali has an annual electricity potential for 32-53 TWh from solar PV using amorphous thin-film silicon as the cheapest option. This potential amount to three times the electricity supply for the island in 2024 which is estimated at 10 TWh. Bali has an excessive potential to support its own electricity demand with renewables, however, some limitations exist with some trade-offs to realize the idea. These results aim to build a developmental vision of solar PV systems in Bali based on available land and the region's irradiation.
\end{abstract}

Keywords: Energy modelling, solar PV, energy policy

\section{Introduction}

The need for decarbonization has been widely acknowledged to resolve externalities. Rectification of COP 21 target to limit global warming below $2^{\circ} \mathrm{C}$ triggers tougher policies, hence oil and gas sector will stretch. The president of Indonesia announced a commitment under the National Determined Contribution during COP 21 in Paris, to reduce emissions by $29 \%$ in 2030. Indonesia also committed to reducing emissions further by $41 \%$ subject to international support. The government has set up a National Development Plan (NDP) to support these initiatives. The NDP includes a policy to increase the contribution of renewables in the Indonesian energy mix by $23 \%$ in 2025 , and $31 \%$ in 2050 . To achieve this, Bali has been appointed as the center of clean energy for Indonesia due to its size, location, people's commitment, and potential for RE plants. The government has created a roadmap for Bali up to 2018 which includes conversion of diesel or coal, development of RE and raising awareness, and also the creation of a research center for clean energy (Sabandar, 2015). However, challenges such as lack of available data, limited tender preparation time, grid interconnection, and proper site selection have hampered the development (Tharakan, 2015).

\footnotetext{
* Corresponding author

E-mail address: ami.syanalia.16@ucl.ac.uk
} 
There are many ways to decarbonize electricity, primarily through a switch to lower carbon sources including RE (Bauen, 2006). Solar PV is the RE source which has the highest potential in Indonesia, particularly in the eastern part of the country, including Bali (IRENA, 2017). There are three ways in which Solar PV may be significantly utilized: in an off-grid setting in remote areas, in utility-scale plants and on both commercial and residential rooftops. PLN has identified five potential solar power plants with 296 MW capacity in Bali and would like to scale-up solar capacity before 2020 to displace diesel power in Indonesia (Tharakan, 2015). Regarding Bali's potential, solar plays a prominent role in providing clean energy. Research shows that Bali's radiation is relatively high with a monthly average of $5.46 \mathrm{kWh} / \mathrm{m}^{2}$ (Rumbayan, Abudureyimu, \& Nagasaka, 2012). There is an excellent opportunity to install solar PV especially in Bali due to the available space, the need for power, and the good infrastructure (IRENA, 2017). Such potential creates opportunities to replace current dieselfired or steam generation supply, and this could contribute to significant cuts in GHG emissions (Brown, 2003).

Bali is an island which lies within the Indonesia archipelago and internationally known as a tourism destination. Tourism generates around $67 \%$ of Bali's regional GDP, and $70 \%$ of the people are dependent directly or indirectly on the industry (Asian Development Bank, 2013). The tourism industry has significantly been supporting economic growth and business in Bali. Indonesian stateowned electricity company (PLN) forecasts that demand will increase by $8 \%$ to $9.6 \%$ per year from 2015-2024. This implies a consumption of more than 10 TWh by 2024. Currently, this demand is supplied by Bali's production of $0.31 \mathrm{GWh}$ from diesel and solar power plants, and a total import of 4,593 GWh from Java Island which mainly generated by steam or diesel plants. Due to this extensive use of fossil fuels, Bali emitted 12.68 tCO2e/capita in 2010 (WRI, 2016). Bali was the top 10 emitting provinces in Indonesia. This number is even higher than the average global emissions of 5 tCO2e/capita (World Bank, 2013). Waste and electricity are the major drivers for Bali's emissions. These emissions impact the seasonal patterns of Indonesia's climate with heavier rainfalls during the wet season and extreme dryness during the dry season. These conditions are expected to affect Bali's population which is located along the coastline. They will suffer from extreme rainfall and flood when sea levels rise. Studies have shown that a $10 \%$ intensification combined with a one-meter sea level rise could affect 14,400 $\mathrm{km}^{2}$ of coastal land (Asian Development Bank, 2016).

This study aims to assess the potential of solar PV to decarbonize energy in Bali. This is important as $\mathrm{RE}$ is a relatively new option for Indonesia, and hence, research about RE is limited. This study focuses on the assessment of solar PV potential in Bali using a spatial modelling approach with GIS. Solar PV will be assumed to decrease emissions when the available potential replaces current fossilfueled generator supply. Presently, Bali does not have a full picture of its RE potential, particularly in the case of solar PV. As a center for clean technology in Indonesia, it is important for Bali to take notable steps towards energy decarbonization using RE technologies such as solar PV.

\section{Methods}

This research assessed the potential of solar PV in Bali based on land suitability using GIS software and analyzed the environmental as well as the economic impact from the deployment of solar PV in four scenarios: BAU, penetration of solar (min), aggressive penetration of solar (max), and rooftop solar PV. The current research focuses on grid-connected PV potential based on land availability.

\subsection{Site Selection Criteria}

Decision criteria to select suitable sites consist of restrictions and factors related to environmental and economic objectives. Restrictions are defined to eliminate areas where solar PV is not suitable. Factors are defined to include areas where solar PV is preferable or suitable. Restrictions and factors will be expressed in GIS using layers as defined by current legislation, which includes residential, agriculture, lakes, etc. This study aims at assessing the potential of solar PV for grid-connected sites, which meet the restriction and factor requirements. Figure 1 describes how the decision model was established. 


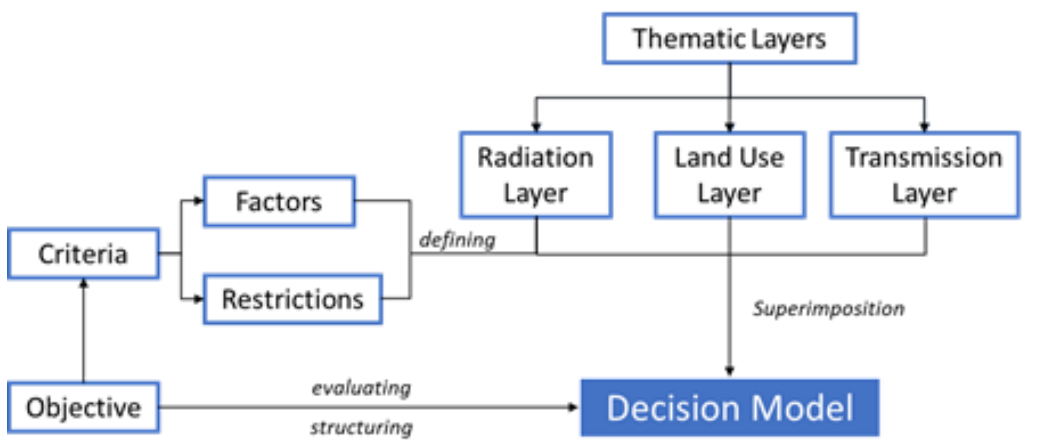

Figure 1. Elaboration of the Decision Model

Decision criteria help to select appropriate locations for PV panels spatially. A literature review was conducted to define the decision criteria to be adopted.

Environmental Objectives (Envi)

1. Constructions are allowed on forest areas if the activities are highly important for public interest (Aydin, Kentel, \& Sebnem Duzgun, 2013).

Bali is surrounded by mountainous forest area, which accounts for $23.18 \%$ of the total area. Forests in Bali help to avoid erosion and flood. Construction of solar PV systems on forest area is still considerable subject to government review.

2. Development on agricultural land is allowed for an approved purpose, while conservation, tourism, and protected areas must be preserved (Aydin et al., 2013).

Local regulations prohibit the conversion of irrigated rice fields. Regulations on sustainable food cultivation indicate that at least $90 \%$ of the area of cropland that exists beyond required land for food, should be devoted to public facilities (Provincial Government of Bali, 2015). Therefore, review and approval should be obtained before land development.

3. A minimum $2.5 \mathrm{~km}$ buffer zone from lakes and wetlands (Aydin et al., 2013).

Bali Province has four main lakes, which serve as a buffer for the water system in the downstream and surrounding areas. New construction should maintain a buffer of at least $2.5 \mathrm{~km}$ from lakes and wetlands to protect topographic and ecologic features.

4. Minimum $100 \mathrm{~m}$ from the coastline (Aydin et al., 2013).

Construction along the coastline is allowed only to support coastal recreation activities, coastal security, fishing activities and port activities. Other types of construction are not allowed. Other buildings should maintain a distance of at least 100 meters from the highest tide point of the sea to the land (Provincial Government of Bali, 2015).

Economic Objectives (Econ)

1. Minimum solar radiation of $4.5 \mathrm{kWh} / \mathrm{m}^{2} /$ day (EIEI, 2009).

This criterion defines the electricity production capacity of solar PV. Bali has an average of 5.33 to $5.37 \mathrm{kWh} / \mathrm{m}^{2} /$ day and an average of 12 hours of sun per day. Therefore, all areas in Bali meet the requirements for $4.5 \mathrm{kWh} / \mathrm{m}^{2} /$ day.

2. Maximum distance to transmission line of 0.5 miles to avoid additional costs (Environmental protection agency, n.d.).

Long distance lines between solar PV panels and the transmission system will increase the loss of power and cost of construction. Ideally, sites should be close to the existing power grid.

3. Maximum distance to urban areas is $10 \mathrm{~km}$ (Arán Carrión et al., 2008).

Solar technologies cause no noise or pollution; hence, PV sites are often installed next to consumers. This helps to reduce the cost and is widely accepted by communities, unlike other renewable energy technologies. Alam et al. (2011) note that densely populated urban and electrified areas are a potential market for grid-connected PV systems. According to Aran et al. (2008), the distance of solar PV plants to urban areas should fall between $5-10 \mathrm{~km}$. This criterion excludes solar PV on rooftops or unused land under a solar PV rooftop scenario. 


\subsection{Data}

This study used secondary data set from many sources. The data are mostly in the form of shapeformat data (GIS) for land use, radiation, power generation, transmission, and distribution. Particularly for solar radiation in Indonesia, the national agency has limited meteorological stations with reliable and calibrated pyranometers; most of them provide information on humidity, temperature, wind speed, and sunshine duration. Therefore, radiation data were derived from the NASA website (http://eosweb.larc.nasa.gov) which has complete data for each longitude and latitude. The primary input to this model included the annual average of insolation on a horizontal surface for each latitude and longitude of all districts in Bali. Masters (2004) stated that measurement of average insolation in clear and cloudy conditions should start with measuring how much sunlight impinges on a horizontal surface. Secondly, this study utilized land use data of Bali from the Geospatial Information Agency (BIG), Government of Indonesia. It contains a spatial map of regions including residential, forest, lakes, airports, coast, etc. To enrich the spatial model, additional district level data were collected from Statistics Indonesia. Lastly, PLN provided a map of generation, transmission, and distribution systems in Bali from the Business Plan for Power Supply report (PT PLN, 2014).

\subsection{GIS Modelling}

GIS has been increasingly used as a tool for spatial planning and optimal site selection for renewables. Spatial analysis operations such as proximity and overlay were used to incorporate layers for land suitability evaluation. Suitability is defined as satisfaction of the set of minimal qualitative and physical constraints imposed by the criteria. Another analysis function, buffer analysis, is one of the most important functions in this regard. It analyses zonal areas of a specific distance around restrictions, namely buffer zones, and identifies the impact and service range in the surrounding environment (Hehai, 1997). In this study, buffer analysis is applied using the function such as full, left, and right. This approach is necessary to define an allowable area for the buffer. Another analysis used in this study was the intersect analysis to overlay all layers. It integrates two or more layers while preserving common features to all layers, similar to the operation of the Boolean AND.

\subsection{Scenarios}

Scenarios are typically used to evaluate potential future energy systems and their implications. They illustrate different consequences and benefits for different implementations, which allow policymakers to make decisions based on preferred scenarios. Four scenarios were tested in this research: (1) BAU - no installment of solar PV; (2) Scenario min - requires instalment of PV considering all restriction criteria; (3) Scenario max - requires instalment of PV considering strict restriction criteria of lakes, wetlands, and coastline; (4) Solar PV rooftop potential which can be added to Scenarios 2 and 3 to illustrate a bigger picture of total solar PV potential. Figure 2 summarizes these scenarios. The strict restriction is a criterion that strictly prohibits the land development in restricted areas. The moderate restriction is a criterion that allows land development in restricted areas with the provision of approved proposals from the government. 


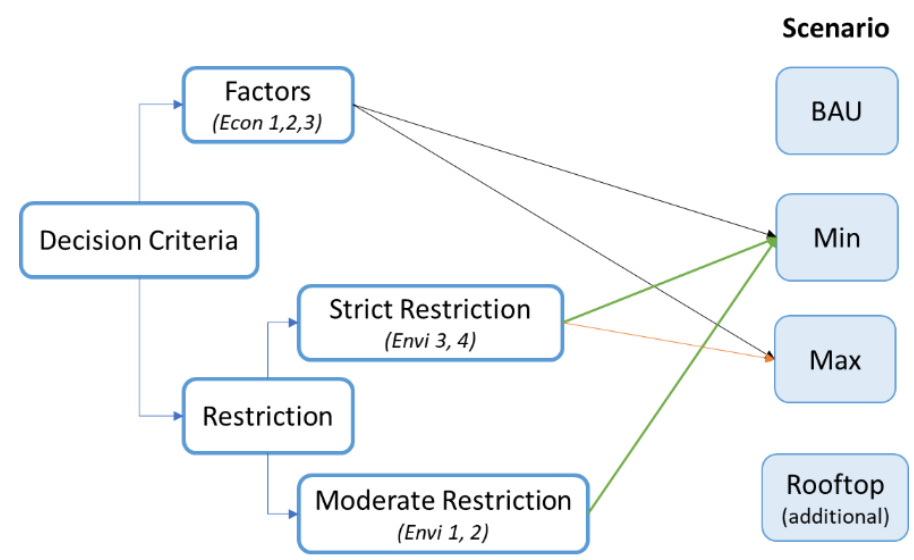

Figure 2. Decision criteria for scenarios

BAU is a scenario where solar PV is not deployed. It describes the situation where the municipal government decides to maintain the current system with fossil-fueled generators and import of electricity from Java. This condition may happen when there are no initiatives to drive renewable development from the municipal or principal government. Scenario min describes low penetration of solar PV. Scenario min is devoted to using the areas that fit all criteria from factors and restrictions. All Strict and moderate restriction criteria are valid input to GIS. Scenario min presents a modest approach to the development of solar PV in Bali. Coal-fired plants have been profoundly considered to increase capacity in Indonesia. However, due to the unfavorable response from international, Indonesia might consider a more significant portion of renewables, which could lead to the rise of renewable energy or solar PV (Deloitte, 2016). This scenario aims to give information to policymakers regarding how emissions can be reduced with the installation of solar PV on available land while keeping current planning. If policymakers consider expanding beyond today, scenario max will show the future projection of a more ambitious approach. Scenario max looks at the inclusion of forest and agriculture land because construction on these areas is possible with an approved proposal. Additionally, both scenarios might consider other plausible strategies to increase solar PV penetration through the installment of PV panels on $10 \%$ of the rooftop and building area (scenario rooftop). Rooftop solar PV in urban areas can improve the self-sufficiency of electricity supply (Seme, Borut, \& Lukac, 2013). However, there are many factors influencing suitable roof areas for solar PV: (1) shading due to neighboring buildings or trees; (2) other use of rooftops such as ventilation, heating, etc.; (3) roof orientation and (4) installation and racking of PV panels (Wiginton, Nguyen, \& Pearce, 2010). Taking account of these factors is of interest for future research. Finally, when sites have been selected for each scenario, the total capacity, total generation, and total emissions savings can be calculated to evaluate the potential role of PV in decarbonizing energy in Bali.

\subsection{Methodology}

There are two applications for solar PV: (1) installation in regions outside of built-up areas with the potential for large-scale PV and (2) installation on rooftops within built-up areas (Sun et al., 2015). In this research, the two application models are assessed. The solar PV geographical potential for suitable areas is estimated by equation (1). Input for the suitable areas was derived from GIS evaluation by excluding restrictions and including factors.

\section{(1) Geographical potential $\mathrm{PG}=\mathrm{R} \mathrm{W}$}

(Sun et al., 2015)

PG is the geographical potential of built-up areas in GWh, R is the annual total solar radiation in $\mathrm{kWh} / \mathrm{m}^{2} /$ day, and $\mathrm{W}$ is the available land area for solar PV in $\mathrm{km}^{2}$. For rooftops, $\mathrm{W}$ is defined as the total residential area in Bali with a probability of $10 \%$ solar PV installation. Furthermore, the potential annual electricity production of grid-connected PV (Ep,PV,pot) in Bali can be calculated by equation (2). Ep,PV,pot estimates the total electric power generation per year, which can also be referred to as the technical potential, with certain assumptions regarding the PV modules to be used. 
dy is the number of days per year, and $\eta$ is the efficiency of the PV module types as shown in Table 1. This study uses the maximum efficiency of each PV module. PR is the performance ratio using an assumption of $75 \%$. An estimation of installed capacity (Cp) can next be made using equation (3). This study assumes an average capacity factor (CF) of $16 \%$, and number of sunshine hours per day (hd) of 12 hours for Bali.

$$
\text { (3) } \mathrm{Cp}=\frac{\mathrm{E}_{p P V_{p o t} x 10^{9}}}{d_{\mathrm{y}} x \mathrm{~h}_{\mathbb{d}} x C F}
$$

(Veldhuis \& Reinders, 2013)

Table 1. PV technical details. (Zahboune, Kadda, \& Zouggar, 2014)

\begin{tabular}{|c|c|}
\hline PV technology & Maximum Efficiency $\boldsymbol{\eta}(\mathbf{\%})$ \\
\hline Mono-Si & 17 \\
\hline Multi-Si & 14 \\
\hline a-Si & 8 \\
\hline $\mathrm{CdTe}$ & 12 \\
\hline
\end{tabular}

After that, total emission can be estimated by calculating emission factors with total power generation output from each scenario. Solar PV appears to be completely clean energy without environmental impact. However, it consumes energy and emits GHG during its lifetime, such as through the manufacture of PV modules and the balance system (BOS), solar cells, transportation, installation, retrofitting, and recycling. Therefore, this research uses several references to estimate solar PV and fossil-fueled generator emissions factors: (1) An emissions factor for solar PV of $45 \mathrm{gCO} 2-\mathrm{eq} / \mathrm{kWh}$ (Fthenakis, Kim, \& Alsema, 2008) and (2) an emissions factor for the Java-Bali grid system in 2024 of $0.697 \mathrm{~kg} \mathrm{CO} 2 / \mathrm{kWh}$ (PT PLN, 2015).

Finally, the commercial benefits can be analyzed further. They represent important information for policy makers about investment strategy. Over the last few years, the price of PV has been exponentially decreasing with the average international cost now below \$1 USD/Wp (ADB, 2015). The cost is projected to continuously fall in the future due to international support and development. Solar PV modules account for the biggest contribution to the total system cost at around $30-40 \%$ of the total installed cost (Ramli, Hiendro, \& Al-Turki, 2016). The falling price has spurred subsequent falls in other costs such as frames, inverters, switchboards, etc. Table 2 shows the assumption costs of generators to analyze the model commercially.

Table 2. Cost assumptions

\begin{tabular}{|c|c|c|c|c|c|c|}
\hline & \multicolumn{4}{|c|}{ Solar PV } & \multirow{2}{*}{$\begin{array}{l}\text { Fossil- } \\
\text { Fuelled }\end{array}$} & \multirow[b]{2}{*}{ Source } \\
\hline & Mono-Si & Multi-Si & $\mathrm{a}-\mathrm{Si}$ & $\mathrm{CdTe}$ & & \\
\hline \multicolumn{7}{|l|}{ Investment Cost } \\
\hline PV Module USD/Wp & 0.8 & 0.6 & 0.7 & 0.6 & & (Alfonso 2014) \\
\hline Inverter USD/Wp & \multicolumn{4}{|c|}{0.14} & & (Mayer et al. 2015) \\
\hline BOS USD/Wp & \multicolumn{4}{|c|}{0.4} & & (Mayer et al. 2015) \\
\hline \multicolumn{7}{|l|}{ O\&M cost } \\
\hline Fuel-coal USD/MWh & \multicolumn{4}{|c|}{ - } & 31.95 & (Parkinson 2015) \\
\hline Fuel-diesel USD/MWh & & & & & 327.12 & \multirow{2}{*}{ (FS-UNEP 2016) } \\
\hline $\begin{array}{l}\text { Variable-coal } \\
\text { USD/MWh }\end{array}$ & & & & & 4 & \\
\hline Fixed O\&M cost & \multicolumn{4}{|c|}{$1.5 \%$ total investment cost } & & (Blum et al. 2013) \\
\hline
\end{tabular}




\section{Comparison of Energy Benefit}

\subsection{Scenario Analysis BAU}

Scenario BAU assumes no effort will be made to deploy solar PV in Bali. Therefore, the current projection of electricity demand and emissions will be used. PLN projects a consumption of 10.537 GWh per year by 2024 in Bali. Under the current system, $99 \%$ of electricity is imported from Java through the Java-Bali grid system. The remaining $1 \%$ of electricity is generated by renewables. If no action is taken to strengthen energy security and decarbonization through renewables, Bali needs to import $10.431 \mathrm{GWh}$ by 2024. Scenario BAU creates emissions of 7.2 million tCO2e, or 2 $\mathrm{tCO} 2 \mathrm{e} /$ capita, under the BAU scenario from imported electricity if we assume the same population of 3.8 million people. These emissions come solely from the electricity sector and exclude emissions from waste, which is also a major issue in Bali. The system brings 374 million USD to 3.4 billion USD of electricity production costs for fossil-fueled electricity depending fuel generation type (coal or diesel).

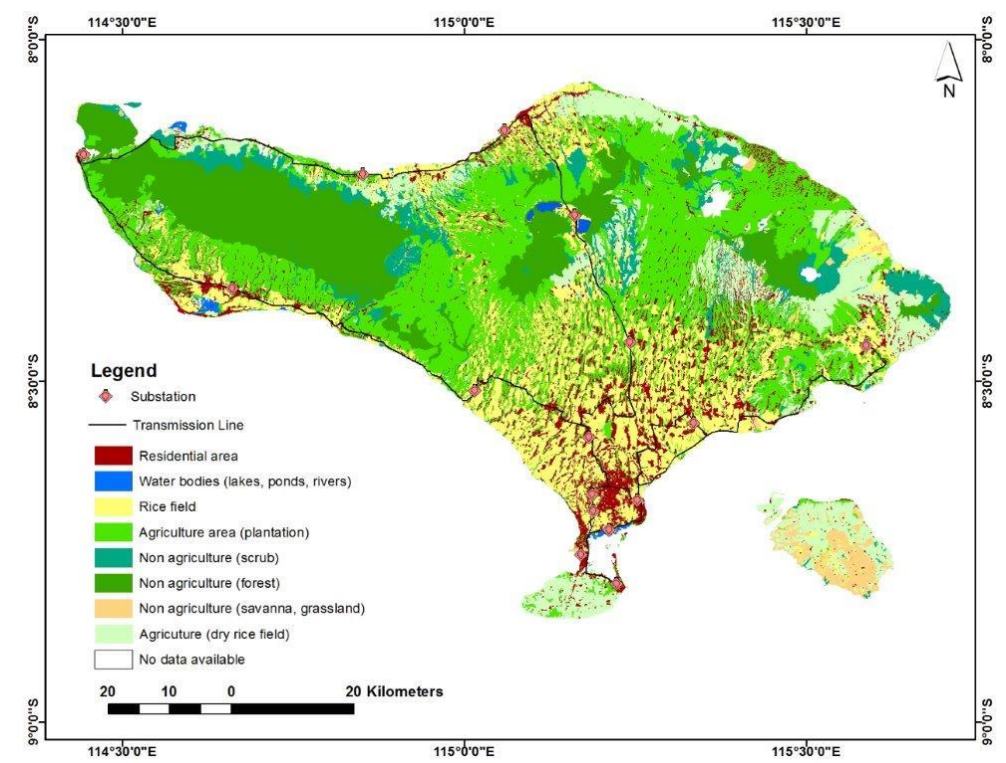

Figure 3. Land use in Bali. (BIG 2010)

\subsection{Scenario Analysis Min}

Scenario min considers all decision criteria that were set in the model. Existing grid criteria play a key role in determining the suitable areas. Grid criteria ensure that the model places solar PV close to transmission lines (within 0.5 miles) to avoid additional cost and the need for storage. Hence, suitable areas tend to follow the transmission lines with exclusion based on other restriction criteria, which intersect, such as forests, agriculture, and lakes. Using these boundaries, the total geographical potential for solar PV is $1461.7 \mathrm{GWh}$ on $273 \mathrm{~km}^{2}$ of suitable area. If monocrystalline silicon (mono$\mathrm{Si}$ ) was used, this generates the highest annual electricity production of $68 \mathrm{TWh}$ compared to other materials. The minimum possible power generation is produced by amorphous silicon (a-Si) with 32 TWh. The results are supportive of previous studies conducted by Veldhuis \& Reinders (2013) on the potential of solar PV in grid-connected systems in Indonesia. According to their study, Indonesia has a potential for $1492 \mathrm{TWh}$ in total, where Bali contributes 2-5\% from results of the current model. Hence, this study indicates that solar PV technology will be able to supply a maximum $68 \mathrm{TWh} /$ year replacing current diesel-power generators. The potential for solar PV in Bali is thus very large and amounts to the 2024 electricity requirement of the whole island, with the option to export to surrounding areas. It accounts for a 33\% contribution to the national electricity requirement by 2024 . The minimum installed capacity for this scenario is estimated at $21.9 \mathrm{GW}$ depending on the PV modules used. Figure 4 depicts a geographical potential map for solar PV in Bali under scenario min. 


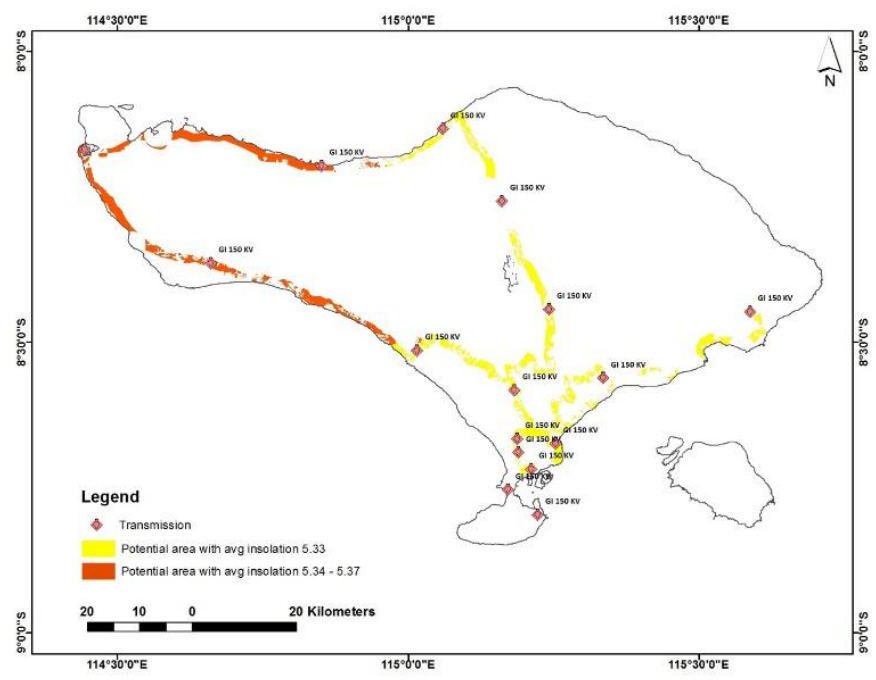

Figure 4. Geographical potential map of solar PV in scenario min.

\subsection{Scenario Analysis Max}

Scenario max ignores moderate restrictions, assuming the government approves land development proposals. The suitable area represents the potentially exploitable areas, including forests and agriculture, between transmission line buffer zones, and sensitive areas restricted previously in the criteria. In this scenario, forest and agriculture are classified as exploitable areas. Using these boundaries, the total geographical potential for solar PV is $2435.7 \mathrm{GWh}$ on $453 \mathrm{~km} 2$. Production of power generation using monocrystalline silicon (mono-Si) is $113 \mathrm{TWh}$ while amorphous silicon (a-Si) is $53 \mathrm{TWh}$. This supports approximately $6.9 \%-24 \%$ of 2024 national electricity requirements. Since scenario min amounts to the supply of the full energy requirements in Bali by 2024, scenario max presents a higher potential for Bali to export electricity. Installed capacity for the scenario is estimated at around 36-77 GW depending on the technology used. Figure 5 shows a geographical potential map of solar PV in Bali.

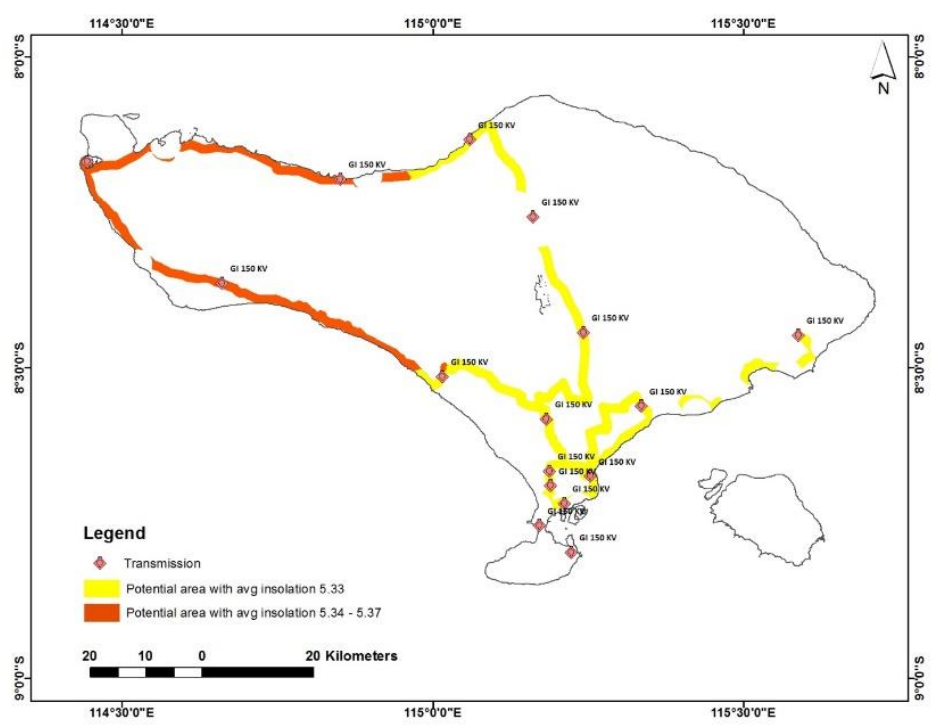

Figure 5. Geographical potential map for solar PV in scenario max.

Bali could potentially satisfy its future electricity demand by its own production of solar energy even in scenario min with moderate effort of solar PV deployment. Scenario max might be considered when Bali needs more ambitious effort to export electricity to its surrounding remote areas, especially off-grid rural areas. Both scenarios will generate approximately 0.47 million $\mathrm{tCO} 2 \mathrm{e}$ and reduction of 
6.8-million tCO2e compare to BAU level, if we assume full solar deployment to meet electricity demand in 2024. Theoretically, it is not feasible to solely rely on solar PV without storage system to satisfy electricity demand. If we assume hybrid technology solar PV and diesel is used, both scenarios will generate emission of 3.87 million tCO2e and reduction of 3.4 million tCO2e. However, this presents a potential estimate that could be achieved without considering current resources and technical requirements needed to realize this capacity in 2024. Other opportunities for increasing solar deployment in the market involve the use of rooftop solar PV on buildings.

\subsection{Scenario Analysis Rooftop}

The possibility of installing rooftop solar PV, mounted on the roof or integrated into the building, is presented for both scenarios. Rooftop PV has a significant potential to add generation to the Java-Bali system (ADB, 2015). The size of the installation and energy output may vary depending on the building's size and available rooftop space. Rooftop solar PV technologies help to increase decarbonization rates and energy security without exploiting currently available space. The total residential and business area in Bali is $488 \mathrm{~km} 2$. If this study assumes $10 \%$ penetration of PV panels on rooftops, the total target area amounts to $48.8 \mathrm{~km} 2$. It could potentially generate $5.7 \mathrm{TWh}$ of electricity annually with $3.9 \mathrm{GW}$ of installed capacity using an a-Si module and account for $37 \%$ of regional electricity consumption in 2024 with an emissions reduction of 2.55 million tCO2e. Since the total potential could not fully satisfy electricity demand, we assume the use of hybrid solar PV and diesel generation in the calculation of emissions. Table 3 summarizes results of each scenario analysis including rooftop solar PV.

Table 3. Summary of the result

\begin{tabular}{|l|r|r|r|r|}
\hline & \multicolumn{1}{|c|}{ BAU } & \multicolumn{1}{c|}{ Min } & \multicolumn{1}{c|}{ Max } & \multicolumn{1}{c|}{ Rooftop } \\
\hline Total demand by 2024 (GWh) & 10,431 & 10,431 & 10,431 & 10,431 \\
\hline Population (Million) & 3.8 & 3.8 & 3.8 & 3.8 \\
\hline Land Area $\left(\mathrm{km}^{2}\right.$ ) & $5,800.0$ & $5,800.0$ & $5,800.0$ & $5,800.0$ \\
\hline Suitable Land Area $\left(\mathrm{km}^{2}\right)$ & - & 273.4 & 455.7 & 48.8 \\
\hline Solar energy potential $(\mathrm{GWh})^{*}$ & - & 32,011 & 53,342 & 3,904 \\
\hline Potential import electricity $(\mathrm{GWh})$ & - & 21,580 & 42,911 & - \\
\hline Emission (tCO ${ }_{2 \mathrm{e}}$ /capita) & 2 & 0.12 & 0.12 & 1.24 \\
\hline Total emission (million $\mathrm{tCO}_{2 \mathrm{e}}$ ) & 7.27 & 0.47 & 0.47 & 4.72 \\
\hline Emission Reduction (tCO ${ }_{2 \mathrm{e}}$ ) & & 6.80 & 6.80 & 2.55 \\
\hline$\%$ of National Electricity Consumption & - & $15.8 \%$ & $26.3 \%$ & $1.9 \%$ \\
\hline$\%$ of Regional Electricity Consumption & $0 \%$ & $307 \%$ & $511 \%$ & $37 \%$ \\
\hline *using a-Si & & & & \\
\hline
\end{tabular}

\subsection{Economic Analysis}

The price of PV modules and systems differs widely depending on suppliers, size, type, and country. Currently, there are no PV module manufacturers in Indonesia. The market consists of less than ten small local companies for assembling PV modules using imported components from neighboring countries such as China and Taiwan (ADB, 2015). Hence, the PV system cost largely depends on international factors. In this model, a large amount of solar PV potential has been identified. The investment required to install solar PV is significant. The cost for solar PV in Indonesia ranges between USD 1.1 to $1.3 / \mathrm{Wp}$. Hence, at least 7.9 billion USD should be invested to replace current fossil-fueled supply if we assume full utilization of solar PV. This cost is estimated at 7.15 GW installed capacity to satisfy $10 \mathrm{TWh}$ demand by 2024. This accounts for half of the expected total investment of new RE projects in Indonesia, of which solar only accounts for $0.87 \mathrm{GW}$ out of a total of $9 \mathrm{GW}$ from various RE sources (Group, 2014). On the other hand, under BAU scenario, Bali still imports electricity from Java island which mainly generated by coal and diesel. If we assume current fossil-fueled generators are utilized, under the same demand assumption, the total cost for generating fossil-fueled electricity is 374 million USD to 3.4 billion USD per year. Hence, the cost for continuing the use of fossil-fueled plant is still cheaper than new deployment of solar PV, which requires capital investment. However, if we consider other costs such as renewal of generators which are old, 
corrective maintenance for any machine failure, fuel subsidies, and the total cost of generator's lifetime, thus employing fossil-fueled generators might be higher than solar PV. This is a further topic of interest for future study.

Levelized cost of electricity (LCOE) for grid-connected PV in these scenarios has been analyzed. LCOE for Solar PV is $0.19 \mathrm{USD} / \mathrm{kWh}$ while coal is $0.13 \mathrm{USD} / \mathrm{kWh}$ under the assumptions as presented in Table 4.

Table 4. LCOE Assumptions

\begin{tabular}{|l|r|r|}
\hline Technology Assumptions & IGCC Coal & Large Scale Solar PV \\
\hline Investment Cost (USD/kW) & 4,523 & 1,350 \\
\hline Annual load factor & $90 \%$ & $11 \%$ \\
\hline Efficiency & $36 \%$ & $15 \%$ \\
\hline Discount rate & $10 \%$ & $10 \%$ \\
\hline Lifetime & 25 & 25 \\
\hline Annual degradation & $0.50 \%$ & $0.50 \%$ \\
\hline Operations cost & $4.29 \%$ & $2.26 \%$ \\
\hline Fuel cost (USD/MWh) & 12.6 & 0.0 \\
\hline Fuel CO2 emission factor (tCO2/MWhf) & 0.033 & $\mathrm{~N} / \mathrm{A}$ \\
\hline
\end{tabular}

According to PLN, average electricity tariff for residential is $0.07 \mathrm{USD} / \mathrm{kWh}$ with subsidized electricity tariff in 2017 is $0.03 \mathrm{USD} / \mathrm{kWh}$ to $0.04 \mathrm{USD} / \mathrm{kWh}$ and regular electricity tariff is 0.09 $\mathrm{USD} / \mathrm{kWh}$ to $0.1 \mathrm{USD} / \mathrm{kWh}$. Solar PV is far from being competitive to government's electricity tariff. Meanwhile, the real generation cost for PLN is $0.09 \mathrm{USD} / \mathrm{kWh}$ on the average ( $\mathrm{PwC}, 2017)$. Ideally, electricity tariff should be equal with cost of electricity production. If subsidies were present which makes electricity tariff lower than original production cost, it will induce more electricity consumption from customers while hindering other new energy alternatives to grow. Electricity subsidy has made cost for renewables ineffective thus increase the tariff gap. In other countries, LCOE gap between Solar PV and other conventional energy has been reduced by introducing carbon price or incentives for renewables.

\subsection{Policy Analysis}

In Indonesia, the price of electricity is heavily subsidized by the government. The aim is to protect the people from price fluctuation while also delivering energy access for all households. Indonesia had a USD 27.7 billion budget for energy subsidy in 2014 (IEA, 2016). About USD 19 billion was allocated for oil subsidy and USD 8 billion for electricity, leading to a low consumer electricity price. The vast majority of subsidies are 'price caps' for consumers on electricity, gasoline, diesel, and LPG. In 2015, the government announced the lifting of gasoline subsidies and the reduction of diesel subsidies to a fixed gap of USD 0.07/litre. Meanwhile, electricity subsidy increased to USD $0.042 / \mathrm{kWh}$ in 2014 . These subsidies have hindered the development and investment in RE to compete with conventional technology. Subsidies have also been burdening Indonesia's budget adversely and impacting on the economy. Therefore, the government should start to realize its commitment to deploy more renewable energy technologies (Blum, Wakeling, \& Schmidt, 2013; Hasan, Muzammil, Mahlia, Jannifar, \& Hasanuddin, 2012; Vithayasrichareon, MacGill, \& Nakawiro, 2012) to reduce the dependency on fossil fuels as well as to leverage the local potential. The feed-in-tariff (FIT) was implemented in Indonesia to accelerate investment in RE. However, evidence pointed to the failure of the FIT implementation in Indonesia due to a small gap margin (Holland \& Derbyshire, 2009). Monetary inflation and currency depreciation of the IDR also affected the FIT implementation (Halstead, Mikunda, \& Cameron, 2015).

PLN and its subsidiaries govern Indonesia's electricity sector. However, according to Law No. 30/2009, the government also invites private organizations as Independent Power Producers (IPP) for investment in transmission, distribution, and power generation activities. Based on a Power Purchase 
Agreement (PPA), most of IPPs sell the electricity generated to PLN at a specified price as per the contract. With this model, the low competition was created in the market due to the PLN domination of the right to sell electricity. There is no pricing competition to attract customers or strong competition for IPP to innovate effectively and efficiently. The market is mostly regulated by PLN, which delays the pace of development. Many of the solar PV players also found difficulties in securing financial loans due to a lack of capacity and financial assurance. If the market is liberalized, they may absorb technology experiences quickly, and therefore, increase their technical capacity to engage with financial loans. However, they would not succeed when subsidies are still present. Apparently, solar PV is still the most expensive technological option for Indonesia (Blum et al., 2013). Blum (2013) notes that diesel subsidy plays a critical role in determining commercial competitiveness between solar PV and diesel in Indonesia. Removing 'price cap' subsidy might be an option, which could reflect the price of electricity more closely and fairly. If the government would like to keep the low price for low-income citizens, re-distribution of subsidies could help to target the right consumers and allow allocation of higher effort to the development of RE. Practically, redistribution of subsidies has been successfully implemented when the government of Indonesia lifted fuel subsidies to end-users. They could follow the same best practice in the electricity sector.

\section{Comparison of Energy Benefit}

The total potential of grid-connected solar PV in Bali ranges from 32-68 TWh for scenario min; 53113 TWh for scenario max and 5-12 TWh for rooftop solar PV. Hence, this implies that if Bali is serious about developing the rooftop PV program, they might be able to adequately supply energy requirements for residential or business users by using solar PV. Having these potential values, the total emissions reduction amounts to 6.8 million tCO2e or $1.88 \mathrm{tCO} \mathrm{e} /$ capita compared to the BAU scenario if full solar PV utilization is assumed to meet the demand specified in the model. This indicates a similar range of the findings by Blum et al. (2013) that solar PV in Indonesia could contribute to $91 \%$ emissions reductions under conditions where small diesel generators are still present. Depending on the PV module used, the theoretical installed capacity in this model varies between 22-80 GW, which represents higher estimates than those made by IRENA of $38.7 \mathrm{GW}$ (IRENA, 2017). This is possibly caused by the exclusion of two important factors related to solar PV in this model: intermittency and tilting. Capturing all potential energy is unlikely to be feasible due to technical limitations; however, this study presents the magnitude of the potential that could be developed. The draft report of National Electricity General Plan (RUKN) 2015-2034 notes that Indonesia is targeting $6.4 \mathrm{GW}$ of solar PV installation across the nation by 2025. Despite an abundant potential, the plan only accounts for $29 \%$ of Bali's grid-connected solar PV potential - an underutilized resource. The potential in this study strongly relates to near-grid land availability based on 2010 spatial data in Bali. Therefore, the potential will greatly depend on future land use and expansion of the transmission network in Bali. If the government plans to extend the transmission line in Bali, it will increase the potential; conversely, if large-scale land development is present, it will decrease the potential. The potential emission reduction will change along with the installed capacity and electricity production from the installed solar PV.

In this model, intermittency of sunshine and tilting of the solar panels are neglected due to time constraints of the research. The actual potential might be lower if both factors are considered. Solar PV is designed in a way that operates less than 24 hours per day throughout the year due to the mismatch between peak demand and a peak output of solar generators. Electricity demand in Indonesia peaks at $8 \mathrm{pm}$ when families come home, and then gradually falling as shown in Figure 6. Particularly in Bali, lightning, air-conditioning, and commercial might share the biggest contribution due to the city's reliance on the tourism industry. As tourism city, Bali needs to operate its hotels, shops, cafes, pubs and bars throughout the night which may represent higher demand number at night compare to the graph below. Meanwhile, the electricity production of solar PV starts from around 6 am and reaches a peak at $12 \mathrm{pm}$, before falling to $6 \mathrm{pm}$. It presents a time gap for solar PV electricity production to meet peak demand in Bali. 


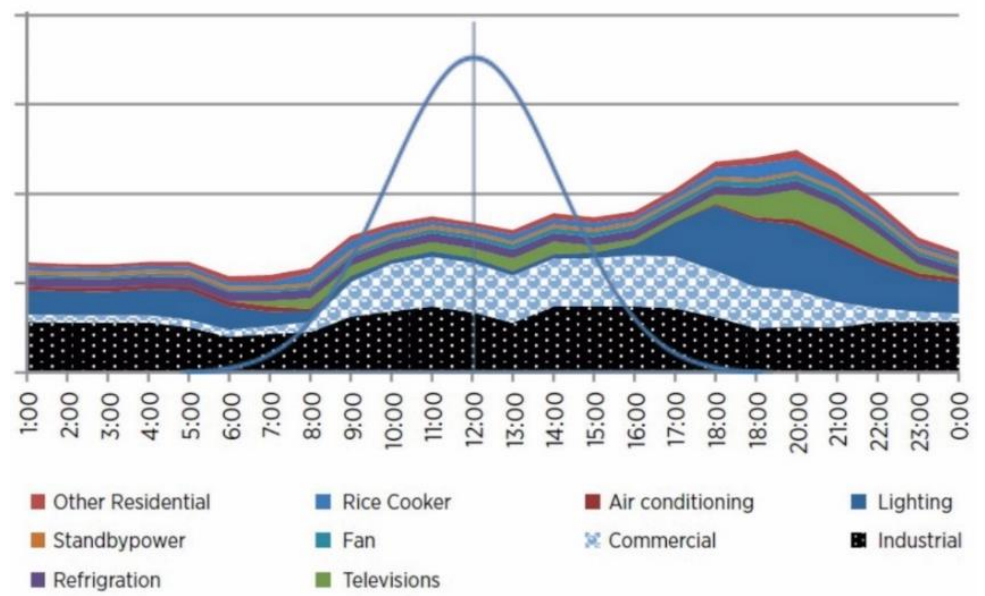

Figure 6. Demand behavior and solar electricity production. (IRENA, 2017)

Hence, in a condition where solar PV operates without storage, it is unlikely that solar PV will exclusively power the whole region without peak load generators that could serve as a backup during peak demand when there is no sun. This is an opportunity for further research to assess the role of storage to meet electricity demand in regions of high solar potential like Bali. Alternatively, Bali could also explore other renewables such as biogas to fill in the gap between peak demand and electricity output from solar PV. Bali is capable to potentially power the whole island with renewables, which help to increase its competitiveness index in tourism industry due to its sustainability in energy (Mowforth \& Munt, 2015).

It was found that investment in solar PV, according to the model, is more expensive by 4.5 billion USD than current diesel-fired plant assuming no replacement of old generators. This is due to the costs of solar PV, which are primarily associated with capital investment and technology limitation such as efficiency of PV module. MEMR stated that the high investment requirement has resulted in RE not being able to compete with subsidized conventional energy (MEMR, 2015). Fuel subsidies have long determined the competitiveness of diesel-fired plant where a major part of the cost comes from fuel. Several recent studies concluded that development of renewables is strongly influenced by fuel subsidies (Glemarec, Rickerson, \& Waissbein, 2012; Waissbein, Glemarec, Bayraktar, \& Schmidt, 2013). Additionally, solar PV could not generate higher output than fossil-fueled generators due to the small efficiency of PV module. This affects the cost of the number of installed capacity. However, solar PV technology has an impressive potential in Indonesia and is expected to experience rapid cost reduction (Braithwaite, Vis-dunbar, Wattimena, \& Wooders, 2012; Terrado, Cabraal, \& Mukherjee, 2008). Re-distribution of subsidies could help solar PV to compete with conventional generators more fairly.

\section{Conclusion}

We attempted to use a spatial modeling approach to determine Bali's solar PV potential that could be exploited to shape a future decarbonization pathway. This model provides an approach, which is closer to an actual potential assessment based on geographical limitations since RE potential is closely linked to geographical location. However, two important factors, intermittency and tilting solar, are reserved for further research. The inclusion of these factors might result in a decrease in estimates of the total potential for solar PV, which can be deployed to decarbonize energy in Bali.

Solar PV shows very promising potential to decarbonize energy in Bali, and yet it appears to be the most neglected energy source. Substitution to a cleaner technology from current conventional generators is seen to be the solution to achieve radical change in decarbonizing the energy sector. With a minimum total potential of $32 \mathrm{TWh}$, we conclude that grid-connected solar PV could play a significant role in decarbonizing energy in Bali. Emission savings that could be generated amounts to 3.4-6.8 million tCO2e. Bali has vast potential to support sufficiently its electricity demand for the 
whole island using solar PV or even export electricity to its surrounding remote islands. However, there are some technical limitations and trade-offs for the deployment. One of the biggest trade-offs is the commercial benefit of solar PV that still becomes the expensive resource for Bali. The cost of solar PV strongly depends on international factors as most of the components are imported. The government might explore opportunities to develop local manufacturer of PV components to reduce the cost and bring other social benefits such as jobs. Intermittency is one of most crucial technical limitation for solar PV. As the availability of sun hours ranging from $6 \mathrm{pm}$ to $6 \mathrm{am}$, solar PV could not satisfy the peak demand during nighttime. Other renewables such as biogas can be explored further to serve electricity demand during peak hours, especially waste as a major contributor of emission in Bali. It can also help Bali to strengthen its energy security by reducing electricity imports and increasing reliance on its own RE sources.

\section{Acknowledgement}

The author extends her gratitude to Fikriyah Winata, a GIS master student at the University of Illinois, for her support in generating GIS model; and Dr. Anandarajah Gabrial, lecturer at UCL, for his supervision in this project. Additionally, the author would like to thank Agra Suryadwipa for his input and insights technically towards the project.

\section{References}

ADB. (2015). Tariff support for wind power and rooftop solar pv in indonesia. Prepared for the Government of Indonesia by the Asian Development Bank, (March).

Arán Carrión, J., Espín Estrella, A., Aznar Dols, F., Zamorano Toro, M., Rodríguez, M., \& Ramos Ridao, A. (2008). Environmental decision-support systems for evaluating the carrying capacity of land areas: optimal site selection for grid-connected photovoltaic power plants. Renewable and Sustainable Energy Reviews, 12(9), 2358-2380. https://doi.org/10.1016/j.rser.2007.06.011

Asian Development Bank. (2013). RRP: Indonesia: Java-Bali 500-Kilovolt power transmission crossing project: economic analysis.

Asian Development Bank. (2016). Indonesia country water assessment. Manila.

Aydin, N. Y., Kentel, E., \& Sebnem Duzgun, H. (2013). GIS-based site selection methodology for hybrid renewable energy systems: A case study from western Turkey. Energy Conversion and Management, 70, 90-106. https://doi.org/10.1016/j.enconman.2013.02.004

Bauen, A. (2006). Future energy sources and systems - Acting on climate change and energy security, 157, 893-901. https://doi.org/10.1016/j.jpowsour.2006.03.034

Blum, N. U., Wakeling, R. S., \& Schmidt, T. S. (2013). Rural electrification through village grids Assessing the cost competitiveness of isolated renewable energy technologies in Indonesia. Renewable and Sustainable Energy Reviews, 22, 482-496. https://doi.org/10.1016/j.rser.2013.01.049

Braithwaite, D., Vis-dunbar, D., Wattimena, B. A., \& Wooders, P. (2012). Indonesia's fuel subsidies: Action plan for reform, (March).

Brown, L. R. (2003). Plan B: Rescuing a Planet Under Stress and a Civilization in Trouble. WW Norton \& Company.

Deloitte. (2016). 35,000 MW: A light for the nation, 1-50.

EIEI. (2009). Personal communications: Caliskan,M.Ankara. Turkey.

Environmental protection agency. (n.d.). Solar Decision Tree. Retrieved March 14, 2017, from http://www.epa.gov/\%0Aoswercpa/docs/solar_decision_tree.pdf

Fthenakis, V. M., Kim, H. C., \& Alsema, E. (2008). Emissions from photovoltaic life cycles. Environmental Science \& Technology, 42(6), 2168-2174.

Glemarec, Y., Rickerson, W., \& Waissbein, O. (2012). Transforming on-grid renewable energy markets. A review of UNDP-GEF support for feed-in tariffs and related price and market-access instruments. United Nations Development Programme (UNDP), New York, NY (United States).

Group, O. B. (2014). The Report: Indonesia 2014: . Oxford Business Group. Retrieved from https://books.google.co.uk/books?id=QtpPCgAAQBAJ

Halstead, M., Mikunda, T., \& Cameron, L. (2015). Policy Brief, Indonesian Feed-in Tariffs: challenges \& options, (Climate \& Development Knowledge Network). 
Hasan, M. H., Muzammil, W. K., Mahlia, T. M. I., Jannifar, A., \& Hasanuddin, I. (2012). A review on the pattern of electricity generation and emission in Indonesia from 1987 to 2009 . Renewable and Sustainable Energy Reviews, 16(5), 3206-3219. https://doi.org/10.1016/j.rser.2012.01.075

Hehai, W. (1997). Problem of Buffer Zone Construction in GIS [J]. Journal of Wuhan Technical University of Surveying and Mapping (WTUSM), 4.

Holland, C. W., \& Derbyshire, W. (2009). Electrifying 20 million households-an indonesian rural electrification strategy. In EEA Conference \& Exhibition June 2009 (pp. 1-11).

IEA. (2016). Fossil fuel subsidy database.

IRENA. (2017). Renewable energy prospects: Indonesia.

MEMR. (2015). Renstra KESDM 2015-2019. DKI Jakarta.

Mowforth, M., \& Munt, I. (2015). Tourism and sustainability: development, globalisation and new tourism in the third world. Routledge.

Provincial Government of Bali. (2015). Laporan status lingkungan hidup daerah bali. Denpasar.

PT PLN. (2014). Rencana Usaha Penyediaan Tenaga Listrik (RUPTL) 2015-2014. DKI Jakarta.

PT PLN. (2015). Electricity supply business plan PT PLN (Persero) 2015 - 2024. https://doi.org/10.1017/CBO9781107415324.004

PwC. (2017). Power in Indonesia: investment and taxation guide, (November).

Ramli, M. A. M., Hiendro, A., \& Al-Turki, Y. A. (2016). Techno-economic energy analysis of wind/solar hybrid system: Case study for western coastal area of Saudi Arabia. Renewable Energy, 91, 374-385.

Rumbayan, M., Abudureyimu, A., \& Nagasaka, K. (2012). Mapping of solar energy potential in Indonesia using artificial neural network and geographical information system. Renewable and Sustainable Energy Reviews, 16(3), 1437-1449. https://doi.org/10.1016/j.rser.2011.11.024

Sabandar, W. (2015). Promoting clean and renewable energy in indonesia, (June).

Seme, S., Borut, Z., \& Lukac, N. (2013). Rating of roofs' surfaces regarding their solar potential and suitability for PV systems, based on LiDAR data, 102, 803-812. https://doi.org/10.1016/j.apenergy.2012.08.042

Sun, Y., Hof, A., Wang, R., Liu, J., Lin, Y., \& Yang, D. (2015). GIS-based approach for potential analysis of solar PV generation at the regional scale : A case study of Fujian Province. Energy Policy, 58(2013), 248-259. https://doi.org/10.1016/j.enpol.2013.03.002

Terrado, E., Cabraal, A., \& Mukherjee, I. (2008). Operational guidance for World Bank group staff: designing sustainable off-grid rural electrification projects: principles and practices. World Bank, Energy and Mining Sector Board, Washington, DC.

Tharakan, P. (2015). Summary of Indonesia's Energy Sector Assessment (ADB Papers on Indonesia No.9). $\quad A d b, \quad$ (9), $40 . \quad$ Retrieved from https://www.adb.org/sites/default/files/publication/178039/ino-paper-09-2015.pdf

Veldhuis, A. J., \& Reinders, A. H. M. E. (2013). Reviewing the potential and cost-effectiveness of grid-connected solar PV in Indonesia on a provincial level. Renewable and Sustainable Energy Reviews, 27, 315-324. https://doi.org/10.1016/j.rser.2015.07.126

Vithayasrichareon, P., MacGill, I. F., \& Nakawiro, T. (2012). Assessing the sustainability challenges for electricity industries in ASEAN newly industrialising countries. Renewable and Sustainable Energy Reviews, 16(4), 2217-2233.

Waissbein, O., Glemarec, Y., Bayraktar, H., \& Schmidt, T. S. (2013). Derisking renewable energy investment. A framework to support policymakers in selecting public instruments to promote renewable energy investment in developing countries. United Nations Development Programme (UNDP), New York, NY (United States).

Wiginton, L. K., Nguyen, H. T., \& Pearce, J. M. (2010). Quantifying rooftop solar photovoltaic potential for regional renewable energy policy. Computers, Environment and Urban Systems, 34(4), 345-357.

WRI. (2016). Bali. Retrieved August 30, 2017, from http://cait.wri.org/indonesia/province/Bali

Zahboune, H., Kadda, F. Z., \& Zouggar, S. (2014). The new Electricity System Cascade Analysis method for optimal sizing of an autonomous hybrid PV / Wind energy system with battery storage. 


\section{Appendix A. Details of Potential Result}

Table A1. Summary of Geographical Potential.

\begin{tabular}{|l|r|c|c|}
\hline Scenario & Suitable Area (m2) & $\begin{array}{c}\text { Annual Solar } \\
\text { Radiation (kWh/m2) }\end{array}$ & $\begin{array}{c}\text { Geographical } \\
\text { Potential (GWh) }\end{array}$ \\
\hline BAU & & & \\
\hline Min - built up & $157,770,000$ & 5.33 & 840.91 \\
\cline { 2 - 4 } Total & $115,600,000$ & 5.37 & 620.77 \\
Max - built up & $\mathbf{2 7 3 , 3 7 0 , 0 0 0}$ & & $\mathbf{1 4 6 1 . 6 9}$ \\
\hline Total & $\mathbf{2 8 7 , 8 9 0 , 0 0 0}$ & 5.33 & $1,534.45$ \\
Rooftop & $\mathbf{1 6 7 , 8 3 0 , 0 0 0}$ & 5.37 & 901.25 \\
\hline
\end{tabular}

Table A2. Summary of Technical Potential.

\begin{tabular}{|c|c|c|c|c|c|c|c|c|}
\hline \multirow[b]{2}{*}{ Scenario } & \multicolumn{4}{|c|}{ PV Power Generation (GWh) } & \multicolumn{4}{|c|}{ Maximum Installed Capacity (MW) } \\
\hline & Mono-Si & Multi-Si & $\mathrm{a}-\mathrm{Si}$ & CdTe & Mono-Si & Multi-Si & $\mathrm{a}-\mathrm{Si}$ & CdTe \\
\hline \multicolumn{9}{|l|}{ BAU } \\
\hline \multirow{2}{*}{ Min - built up } & 39,134 & 32,228 & 18,416 & 27,624 & $26,820.9$ & $22,087.8$ & $12,621.6$ & $18,932.4$ \\
\hline & 28,889 & 23,791 & 13,595 & 20,392 & $19,799.5$ & $16,305.5$ & $9,317.4$ & $13,976.1$ \\
\hline Total & 68,023 & 56,019 & 32,011 & 48,016 & $46,620.4$ & $38,393.3$ & $21,939.0$ & $32,908.5$ \\
\hline \multirow{2}{*}{ Max - built up } & 71,410 & 58,808 & 33,605 & 50,407 & $48,941.3$ & $40,304.6$ & $23,031.2$ & $34,546.8$ \\
\hline & 41,942 & 34,540 & 19,737 & 29,606 & $28,745.2$ & $23,672.5$ & $13,527.2$ & $20,290.7$ \\
\hline Total & 113,351 & 93,348 & 53,342 & 80,013 & $77,686.5$ & $63,977.1$ & $36,558.4$ & $54,837.5$ \\
\hline Rooftop & 12,105 & 9,968 & 5,696 & 8,544 & $8,296.0$ & $6,832.0$ & $3,904.0$ & $5,856.0$ \\
\hline
\end{tabular}




\section{Appendix B. Details of Cost Result}

Table B. Summary of Investment.

\begin{tabular}{|l|r|r|r|r|r|r|}
\hline \multicolumn{1}{|c|}{} & BAU - Diesel & BAU - Coal & \multicolumn{3}{|c|}{ Solar PV as per demand } \\
\hline Investment Cost & & & Mono-Si & Multi-Si & a-Si & CdTe \\
\hline Max cost of PV Module (Million USD) & & & & & & \\
\hline Inverter (Million USD) & - & - & 5,362 & 3,932 & 4,933 & 4,218 \\
\hline BOS (Million USD) & - & - & 1,001 & 1,001 & 1,001 & 1,001 \\
\hline O\&M cost & - & - & 2,860 & 2,860 & 2,860 & 2,860 \\
\hline Fixed O\&M cost (million USD) & 3,412 & 375 & 138 & 117 & 132 & 121 \\
\hline GRAND TOTAL (million USD) & 3,412 & 375 & 9,361 & 7,909 & 8,925 & 8,200 \\
\hline
\end{tabular}

\begin{tabular}{|l|r|r|r|r|r|r|r|r|}
\cline { 2 - 10 } \multicolumn{1}{c|}{} & \multicolumn{4}{|c|}{ Scenario Min } & \multicolumn{3}{c|}{ Scenario Max } \\
\hline Investment Cost & Mono-Si & Multi-Si & a-Si & CdTe & Mono-Si & Multi-Si & a-Si & CdTe \\
\hline Max cost of PV Module (Million USD) & & & & & & & & \\
\hline Inverter (Million USD) & 34,965 & 21,116 & 15,138 & 19,416 & 58,265 & 35,187 & 25,225 & 32,354 \\
\hline BOS (Million USD) & 6,527 & 5,375 & 3,071 & 4,607 & 10,876 & 8,957 & 5,118 & 7,677 \\
\hline O\&M cost & 18,648 & 15,357 & 8,776 & 13,163 & 31,075 & 25,591 & 14,623 & 21,935 \\
\hline Fixed O\&M cost (million USD) & & & & & & & & \\
\hline GRAND TOTAL (million USD) & 902 & 628 & 405 & 558 & 1,503 & 1,046 & 675 & 929 \\
\hline
\end{tabular}

